\title{
Pemanfaatan Limbah Cangkang Telur sebagai Pupuk Organik Cair di Kecamatan Rumbai Bukit
}

\author{
Saberina Hasibuan ${ }^{* 1}$, Muhammad Rafi Nugraha ${ }^{2}$, Aufa Kevin ${ }^{2}$, Novan Rumbata ${ }^{2}$, Syahkila $^{3}$, \\ Sekar Asmara Dhewanty ${ }^{3}$, Muhammad Fajar Fadillah ${ }^{3}$, Maya Kurniati ${ }^{4}$, Nana Trilanda ${ }^{4}$, \\ Sherina Nur Afifah ${ }^{5}$, Tevania Shafira ${ }^{5}$ \\ ${ }^{1}$ Jurusan Budidaya Perairan, Fakultas Perikanan dan Kelautan, Universitas Riau \\ ${ }^{2}$ Jurusan Akuntansi, Fakultas Ekonomi dan Bisnis, Universitas Riau \\ ${ }^{3}$ Jurusan Sosiologi, Fakultas Ilmu Sosial dan Ilmu Politik, Universitas Riau \\ ${ }^{4}$ Jurusan Kimia, Fakultas Matematika dan Ilmu Pengetahuan Alam, Universitas Riau \\ ${ }^{5}$ Teknologi Hasil Perikanan, Fakultas Perikanan dan Kelautan, Universitas Riau \\ *Corresponding Author: saberina.hasibuan@lecturer.unri.ac.id
}

Dikirim: 25-08-2021; Diterima: 08-12-2021

\begin{abstract}
ABSTRAK
Limbah cangkang telur dapat dimanfaatkan untuk pembuatan pupuk organik cair. Cangkang telur dapat berasal dari buangan sampah peternakan ayam petelur dan sampah dapur rumah tangga. Pembuatan pupuk organik cair (POC) berbahan baku cangkang telur dilakukan untuk meminimalkan pencemaran lingkungan. Selain itu, daur ulang limbah cangkang telur memiliki nilai ekonomi. Kegiatan pembuatan pupuk organik cair dilakukan oleh 10 orang mahasiswa Kukerta Universitas Riau. Lokasi pembuatan pupuk organik cair di halaman rumah Bapak Masdi Ketua RW 7, Kecamatan Rumbai Bukit. Metode pembuatan pupuk organik cair yaitu dengan fermentasi selama 10 hari dengan suhu sekitar $40^{\circ} \mathrm{C}$. Bahan yang digunakan yaitu cangkang telur, larutan EM4, gula merah, dan air, sedangkan alat yang diperlukan yaitu baskom, botol, alat penggiling, dan termometer. Tujuan pelaksanaan program ini adalah untuk menambah wawasan warga Rumbai Bukit terhadap manfaat limbah cangkang telur dalam pembuatan POC. Selama ini limbah cangkang telur hanya ditumpuk di lahan kosong milik desa dan menjadi sumber polusi udara. Pembuatan POC dari $1 \mathrm{~kg}$ bubuk cangkang telur menghasilkan $500 \mathrm{ml}$ POC. Selama praktik dihasilkan 7 botol POC dengan volume $500 \mathrm{~mL}$ per botol dengan modal Rp5.000,00 per botol. Pengujian POC pada tanaman cabai dan pepaya yang ditanam di pekarangan rumah warga dilakukan dengan pengamatan secara kualitatif terhadap daun yang menunjukkan daun lebih luas daripada tanaman yang tidak diberi POC. Hasil kuesioner partisipasi peningkatan wawasan dan keterampilan masyarakat RW 7 Rumbai Bukit dalam mengikuti kegiatan dan mengembangkan pembuatan POC meningkat sebesar 87,5\%. Kegiatan penyuluhan ini menambah nilai jual limbah cangkang telur. Limbah cangkang telur yang sudah menjadi POC dapat dijual dan mendapat keuntungan sebesar Rp10.000,00. Pemanfaatan limbah cangkang telur sebagai POC dapat meningkatkan perekonomian kelompok ibu Pembinaan Kesejahteraan Keluarga (PKK) sebesar 50\%.
\end{abstract}

Kata kunci: fermentasi, ibu PKK, larutan EM4, limbah cangkang telur, pupuk cair organik

\section{Utilization of Eggshell Waste As Liquid Organic Fertilizer in Rumbai Bukit District}

\begin{abstract}
Eggshell waste can be used for the manufacture of liquid organic fertilizer. Eggshells can come from laying hens farm waste and household kitchen waste. The utilization of liquid organic fertilizer (POC) from eggshell waste is done to minimize environmental pollution. In addition, eggshell waste recycling has economic value. The activity of making liquid organic fertilizer was carried out by 10 Kukerta students, Riau University. The location for making liquid organic fertilizer is in the yard of Mr. Masdi's house, the chairman of RW 7, Rumbai Bukit District. The method of making liquid
\end{abstract}


organic fertilizer is by fermentation for 10 days at a temperature of around $40^{\circ} \mathrm{C}$. The materials used are eggshells, EM4 solution, brown sugar, and water, while the tools needed are a basin, a bottle, a grinder, and a thermometer. The purpose of this program is to increase the knowledge of the residents of Rumbai Bukit on the benefits of eggshell waste in making POC. So far, eggshell waste has only been piled up on vacant land belonging to the village and as a source of air pollution. Making POC from $1 \mathrm{~kg}$ of eggshell powder produced $500 \mathrm{ml}$. During the practice, 7 bottles of POC were produced containing $500 \mathrm{~mL}$ per bottle with a capital of Rp. 5,000 per bottle. POC testing on chili and papaya plants planted in people's yards was carried out with qualitative observations of the leaves which showed wider leaves than plants that were not given POC. The results of the participation questionnaire to increase the knowledge and skills of the RW 7 Rumbai Bukit community in participating in activities and developing POC manufacturing increased by $87.5 \%$. This outreach activity adds to the value of eggshell waste every $1 \mathrm{~kg}$ after it becomes a POC, which is sold for a profit of Rp. 10,000. Utilization of eggshell waste as POC can increase the economy of the Family Welfare Development (PKK) women's group by $50 \%$.

\section{Keywords: eggshell waste, EM4 solution, fermentation, liquid organic fertilizer, PKK mother}

\section{PENDAHULUAN}

Cangkang telur merupakan limbah rumah tangga yang sangat mudah didapat. Cangkang telur dapat juga berasal dari buangan sampah peternakan ayam petelur. Selama ini limbah cangkang telur di Kecamatan Rumbai Bukit hanya ditumpuk di lahan kosong milik desa. Kurangnya pengetahuan dan wawasan masyarakat mengenai pemanfaatan limbah cangkang telur mengakibatkan limbah tersebut dapat mencemari lingkungan. Cara untuk menangani limbah cangkang telur yaitu melakukan pengolahan menjadi pupuk organik cair.

Cangkang telur memiliki kandungan nutrien yang tinggi. Suhastyo \& Raditya (2021) menyatakan bahwa sebanyak 97\% kalsium terkandung dalam cangkang telur ayam. Tingginya kandungan kalsium ini diketahui sebagai senyawa kalsium karbonat yang sangat baik sebagai bahan baku pembuatan POC dan dapat menaikkan $\mathrm{pH}$ media tanah dan air. Machrodania et al. (2015) menambahkan bahwa limbah cangkang telur ayam broiler juga mengandung $\mathrm{CaCO}_{3}$ sebesar 97\%, 3\% fosfor, $3 \%$ magnesium, natrium, kalium, seng, mangan, besi, dan tembaga.

POC lebih mudah diserap kandungan haranya oleh akar tanaman daripada pupuk dengan bentuk padat. Unsur hara yang tersedia di POC secara optimal dapat dimanfaatkan oleh tanaman sehingga dapat berpengaruh lebih baik (Kusumaningtyas et al., 2015). Yunita et al. (2016) menambahkan bahwa unsur hara seperti nitrogen $(\mathrm{N})$ dapat meningkatkan tumbuh tunas, batang, dan daun, sementara unsur fosfor $(\mathrm{P})$ meningkatkan biomassa tumbuh akar, buah, dan biji, dan unsur kalium (K) dapat menaikkan imunitas tanaman dari gangguan dan serangan hama dan penyakit.

Pengolahan limbah menjadi pupuk organik cair biasanya menggunakan teknologi fermentasi yang memanfaatkan mikroorganisme berupa bakteri. Langkah-langkah dalam pembuatan POC adalah menyediakan peralatan untuk membuat POC, menyediakan bahan baku, melakukan pencampuran bahan, fermentasi serta melakukan pengecekan, dan setelah 2 minggu POC siap digunakan (Saenab et al., 2018).

Aplikasi POC yang mengandung ekstrak kulit telur kering telah dilakukan terhadap tanaman cabai dan didapat pertumbuhan paling tinggi (Noviansyah \& Chalimah, 2015). Gani et al. (2021) menambahkan bahwa selain N, P, K yang terkandung di dalam POC, kandungan magnesium dan belerang juga dibutuhkan oleh tanaman. Rahmadina \& Tambunan (2017) menambahkan bahwa pupuk yang menggunakan bahan baku cangkang telur memiliki unsur hara yaitu kadar N 0,18 \%, kadar P $7 \%$, dan kadar K $8 \%$, zat organik $5,2 \%, \mathrm{C}$ atau $\mathrm{N} 30 \%$. Selanjutnya Gani et al. (2021) mengemukakan bahwa unsur kalsium dapat meningkatkan pertumbuhan akar dan tunas. Apabila kebutuhan kalsium tanaman tidak dapat terpenuhi maka dapat menyebabkan kekerdilan dan gugurnya bunga pada tanaman akibat terhalangnya pertumbuhan puncak. Kalsium sangat baik diberikan pada tanaman hias dan tanaman buah.

Manusia dan tanaman memerlukan asupan kalsium dalam tubuhnya. Memanfaatkan cangkang telur untuk tanaman pepaya adalah salah satu solusi dalam pemenuhan kebutuhan kalsium melalui pupuk cair. Brun et al. (2013) menyatakan bahwa cangkang telur ayam 
merupakan sumber $\mathrm{Ca}$ (kalsium) yang tersedia di rumah dan dapat digunakan sebagai suplemen $\mathrm{Ca}$. Kekurangan $\mathrm{Ca}$ dalam makanan adalah masalah umum. Asupan $\mathrm{Ca}$ dari produk susu merupakan cara yang tepat untuk memenuhi $\mathrm{Ca}$. Cangkang telur merupakan sumber kalsium yang tepat dan murah untuk memenuhi nutrisi manusia serta mudah ditemukan di rumah.

Senyawa kalsium karbonat pada cangkang telur dapat larut dalam senyawa asam dan air panas dalam waktu yang lama, sehingga pengolahan pupuk organik cair dibutuhkan dengan larutan EM4 sebagai bioaktivator yang bersifat asam. Fan et al. (2017) mengemukakan bahwa penggunaan EM4 dalam pembuatan POC dapat meningkatkan kadar kandungan hara nitrogen, fosfor, dan kalium daripada pembuatan kompos yang tidak menggunakan EM4. Subandriyo et al. (2012) mendukung bahwa penggunaan EM4 dapat membantu meningkatkan unsur hara pada pupuk.

Limbah cangkang telur di Kecamatan Rumbai Bukit ini berasal dari rumah tangga dan limbah pabrik ayam broiler. Tumpukan limbah ini telah meresahkan masyarakat karena dapat menyebabkan lingkungan menjadi kotor dan aroma bau busuk telur memasuki wilayah pemukiman. Banyak masyarakat yang ingin memanfaatkan limbah cangkang telur ini, namun belum diketahui teknologi tepat guna yang dapat diaplikasikan.

Tujuan dilaksanakan penyuluhan adalah untuk meningkatkan pengetahuan masyarakat RW 7 Rumbai Bukit mengenai manfaat limbah cangkang telur dan teknologi tepat guna yang digunakan serta manfaat pupuk organik cair bagi tanaman jenis sayuran ataupun buah-buahan. Manfaat penyuluhan adalah untuk memberikan keterampilan kepada masyarakat agar dapat mengolah limbah cangkang telur menjadi pupuk organik cair, sehingga dapat meminimalkan pencemaran lingkungan dan membantu perekonomian masyarakat.

\section{METODE}

\section{Pembuatan pupuk organik cair}

Proses pemantapan pembuatan pupuk organik cair dilakukan di Posko KKN RW 7, Kecamatan Rumbai Bukit. Kegiatan ini dimulai dengan melakukan observasi pada tumpukan limbah cangkang telur. Tumpukan ini berasal dari sampah peternakan ayam petelur yang dibuang begitu saja. Kemudian didiskusikan untuk mencari solusi pemanfaatan limbah cangkang telur.

Setelah diketahui kandungan, manfaat serta cara pengolahan cangkang telur, akhirnya dilakukan percobaan membuat pupuk organik cair. Pupuk organik cair diolah dengan metode fermentasi.

Tahap kegiatan pembuatan POC merujuk pada Subandriyo et al. (2012) yang dapat dijabarkan sebagai berikut :

1. Cangkang telur dibersihkan dengan cara dicuci terlebih dahulu (Gambar 1) dan dijemur hingga kering (Gambar 2). Selanjutnya, cangkang telur disangrai agar kering sempurna. Cangkang telur yang telah kering dihaluskan dengan menggunakan alat penghalus. Kemudian cangkang telur yang sudah halus diayak, ditimbang sebanyak $1 \mathrm{~kg}$, dan dimasukkan ke dalam baskom.

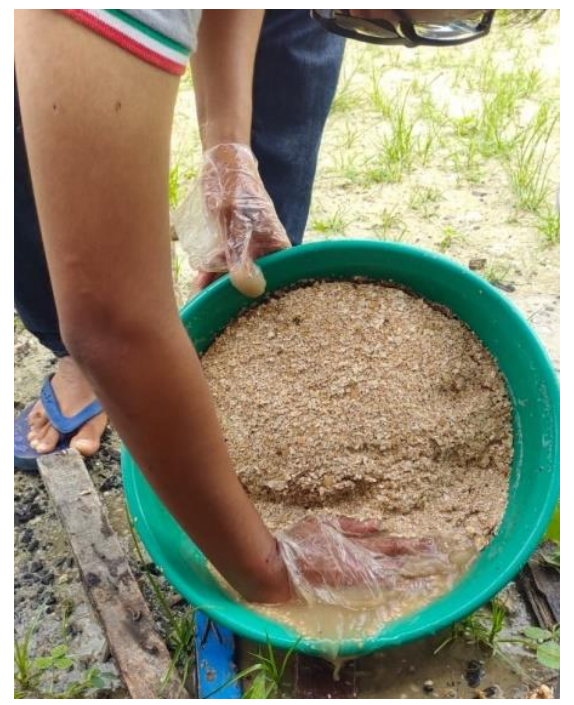

Gambar 1. Proses pencucian cangkang telur

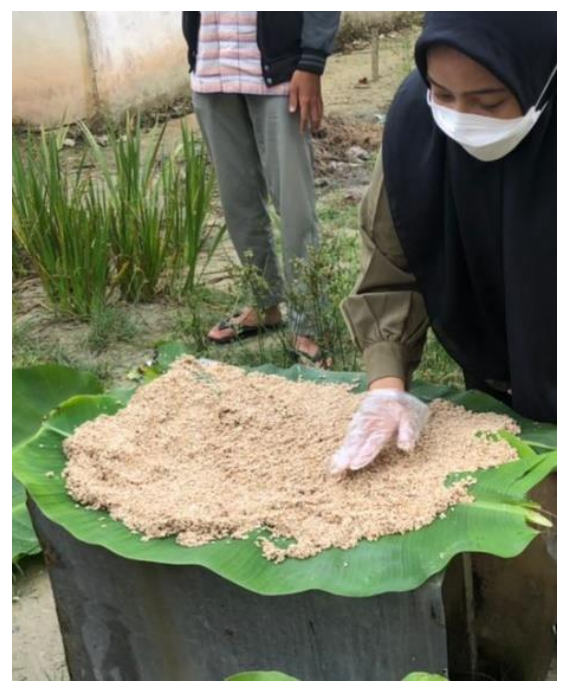

Gambar 2. Proses penjemuran cangkang telur 
2. Gula merah dilarutkan dengan air panas sebanyak $50 \mathrm{~mL}$ dan dimasukkan ke dalam baskom.

3. EM4 ditambahkan air dengan perbandingan 1: 9 (EM4 sebanyak $50 \mathrm{~mL}$ dan air sebanyak $450 \mathrm{~mL}$ ). Larutan EM4 dimasukkan ke dalam baskom.

4. Semua bahan yang ada di dalam baskom diaduk hingga homogen.

5. Larutan dimasukkan kedalam botol dan ditutup rapat, lalu difermentasi hingga 10 hari pada suhu $40^{\circ} \mathrm{C}$.

6. Setelah 10 hari, pupuk organik cair dimasukkan ke dalam botol kemasan

\section{Penyuluhan pupuk organik cair}

Penyuluhan ini dilakukan di halaman rumah Bapak Masdi sebagai Ketua RW 7 di Kelurahan Rumbai Bukit. Kegiatan penyuluhan dihadiri oleh warga RW 7 Kelurahan Rumbai Bukit. Untuk mengetahui antusias warga Rumbai Bukit dalam mengikuti penyuluhan maka diberikan kuesioner sebanyak dua kali yaitu di awal kegiatan dan di akhir kegiatan. Warga diberi kesempatan untuk mengumpulkan cangkang telur serta mengolahnya menjadi pupuk POC. Hasil POC diaplikasikan ke tanaman cabai dan pepaya selama 2 minggu yang ada di pekarangan rumah warga di Kelurahan Rumbai Bukit.

\section{Diskusi dan Evaluasi}

Pada sesi diskusi peserta dipersilakan bertanya kepada tim mahasiswa KKN sebagai penyuluh. Selain itu sikap antusiasme peserta selama jalannya penyuluhan dievaluasi dengan kriteria pada Tabel 1 (Hasibuan et al., 2019). Untuk mengetahui persentase kriteria antusiasme dan sikap peserta selama mengikuti penyuluhan dilakukan pretest dan posttest kemudian dilakukan perhitungan sebagai berikut: (Jumlah peserta pada masing-masing kriteria antusias/jumlah seluruh peserta yang ikut penyuluhan) x $100 \%$.

\section{HASIL DAN PEMBAHASAN}

Pemanfaatan limbah cangkang telur dalam pembuatan POC merupakan salah satu upaya dalam meningkatkan wawasan pemikiran masyarakat dalam pengolahan limbah menggunakan teknologi tepat guna. Bertambahnya ilmu dan keterampilan masyarakat di Kelurahan Rumbai Bukit telah menjadi solusi dalam mengatasi tumpukan limbah cangkang telur. Hasil yang diperoleh dalam $1 \mathrm{~kg}$ limbah cangkang telur kering dengan penambahan $50 \mathrm{~mL}$ EM4 dan $450 \mathrm{~mL}$ air serta difermentasi selama 10 hari adalah $500 \mathrm{~mL}$ POC. Bahan baku pembuatan POC ini dapat dikatakan sebagai kegiatan mengurangi limbah rumah tangga dan peternakan ayam petelur. Hal ini sesuai dengan pernyataan Suhastyo \& Raditya (2021) bahwa cangkang telur adalah sampah rumah tangga yang belum dapat digunakan secara optimal. Kandungan kalsium karbonat yang terdapat pada cangkang telur merupakan kandungan nutrisi yang bagus jika dibuat menjadi pupuk organik. Sebagai POC yang mengandung kadar kalsium yang tinggi sangat baik digunakan untuk menetralkan kadar keasaman tanah.

Kriteria antusiasme dan sikap peserta selama mengikuti penyuluhan (Tabel 1) diperoleh: (1) Sangat rendah (skor 1,0-1,49) sebanyak 0\%; (2) Rendah (skor 1,5-1,99) sebanyak 2,5\%; (3) Sedang (skor 2,0-2,49) sebanyak 10,0\%; (4) Tinggi (skor 2,5-2,99) sebanyak 87,5\%; dan (5) Sangat Tinggi (skor 3,0-3,49) sebanyak 0\%. Berdasarkan Tabel 1 diperoleh nilai antusias warga RW 7 Kelurahan Rumbai Bukit yang tinggi mencapai 87,5\%.

Tabel 1. Kriteria antusiasme dan sikap peserta selama mengikuti penyuluhan

\begin{tabular}{|c|c|c|}
\hline Antusiasme peserta & Skor & Keterangan \\
\hline Sangat rendah & $1,0-1,49$ & $\begin{array}{l}\text { Menunjukkan sikap ogah-ogahan dan meninggalkan } \\
\text { ruangan sebelum acara selesai }\end{array}$ \\
\hline Rendah & $1,5-1,99$ & $\begin{array}{l}\text { Menunjukkan sikap masa bodoh dan tidak memperhatikan } \\
\text { materi yang disampaikan, tetapi tetap berada di ruangan } \\
\text { selama acara berlangsung }\end{array}$ \\
\hline Sedang & $2,0-2,49$ & $\begin{array}{l}\text { Kadang-kadang memperhatikan, tetapi kadang-kadang } \\
\text { melakukan hal lain seperti asyik menggunakan HP }\end{array}$ \\
\hline Tinggi & $2,5-2,99$ & $\begin{array}{l}\text { Menyimak dengan baik, tetapi pasif, tidak aktif dalam } \\
\text { diskusi }\end{array}$ \\
\hline Sangat tinggi & $3,0-3,49$ & Menyimak dengan baik dan aktif dalam diskusi \\
\hline
\end{tabular}


Kegiatan mengolah limbah cangkang telur menjadi POC telah menyebabkan berkurangnya tumpukan limbah cangkang telur yang dibuang oleh pabrik ayam broiler yang terdapat di wilayah Kelurahan Rumbai Bukit.

Pengujian kualitas POC dilakukan dengan mengaplikasikan POC sebagai pupuk bagi tanaman terutama sayuran dan buah-buahan di tanah yang terdapat di pekarangan masyarakat Kelurahan Rumbai Bukit. Aplikasi POC adalah cara pemenuhan kebutuhan nutrien di tanah. Sesuai dengan yang dinyatakan oleh Ji et al. (2017) bahwa pupuk organik umumnya dianggap sebagai cara yang efektif untuk mempertahankan kesuburan tanah dan pertumbuhan tanaman. Penambahan pupuk sangat penting dalam produksi tanaman, terutama pertumbuhan akar.

Aplikasi POC pada tanaman cabai dan pepaya menunjukkan perkembangan dan pertumbuhan yang bagus. Pengamatan secara kualitatif menunjukkan bahwa daun lebih luas ketika tanaman diberi POC. Hal ini sesuai dengan hasil penelitian Brun et al. (2013) yang menyatakan bahwa pupuk cangkang telur mengandung unsur hara esensial bagi tanaman yaitu nitrogen, fosfor, kalium, magnesium, kalsium, belerang, seng, dan klorida (Tabel 2).

Tanah pekarangan yang berada di rumah warga Kelurahan Rumbai Bukit terlihat hitam dan remah. Hal ini diduga ada kaitannya dengan penggunaan POC oleh masyarakat secara berkala dalam meningkatkan unsur hara. Penggunaan POC ini memiliki keuntungan, yaitu mudah dalam pembuatannya dan menggunakan peralatan yang sederhana. Berdasarkan Tabel 2, POC dapat mengatasi defisiensi hara, dalam pencucian hara tidak ada kendala, dan bisa menyediakan hara dengan cepat. Hal ini sesuai dengan pernyataan Nur et al. (2016) bahwa pupuk organik cair biasanya tidak merusak tanah dan tanaman.

Tabel 2. Komponen kimia dalam pupuk cangkang telur

\begin{tabular}{cc}
\hline Kandungan Nutrien & Jumlah Kandungan \\
Cangkang Telur & Nutrien \\
\hline Nitrogen & $0,004 \%$ \\
Fosfor & $4,5 \mathrm{ppm}$ \\
Kalium & $116,8 \mathrm{ppm}$ \\
Kalsium & $78,8 \mathrm{ppm}$ \\
Chloride & $64,8 \mathrm{ppm}$ \\
Sulfur & $10 \mathrm{ppm}$ \\
Magnesium & $23,5 \mathrm{ppm}$ \\
\hline
\end{tabular}

Sumber: Wijaya \& Teo (2019)
Tabel 3. Nilai kandungan N, P, K dan C dalam sampel lindi

\begin{tabular}{cll}
\hline Kandungan POC & Hari ke-14 & Hari ke-17 \\
\hline N & $0,181 \%$ & $0,205 \%$ \\
P & $0,0063 \%$ & $0,0074 \%$ \\
K & $0,1193 \%$ & $0,1138 \%$ \\
C & $0,336 \%$. & $0,27 \%$, \\
\hline
\end{tabular}

Sumber : Nur et al. (2016)

Selain itu, pupuk ini mengandung unsur kalium yang berperan penting dalam setiap proses metabolisme tanaman, sehingga larutan pupuk yang diberikan ke permukaan tanah secara langsung bisa diserap tanaman. Semakin lama proses pembuatan pupuk organik cair, maka akan meningkatkan kandungan $\mathrm{N}, \mathrm{P}, \mathrm{K}$, dan $\mathrm{C}$ dalam sampel lindi yang dihasilkan (Tabel 3). Simanjuntak et al. (2016) menyebutkan bahwa pupuk organik cair cocok bagi pertumbuhan sayuran dan buah-buah.

Pembuatan POC menggunakan larutan EM4 karena kalsium karbonat yang terdapat pada cangkang telur tidak dapat larut dalam air. Senyawa kalsium karbonat mampu larut di dalam larutan yang bersifat asam. Oleh sebab itu, pembuatan pupuk organik cair menggunakan larutan EM4 sebagai bioaktivator yang bersifat asam. Selain itu, pupuk yang ditambahkan EM4 menghasilkan kandungan hara nitrogen, fosfor, dan kalium yang lebih tinggi daripada kompos tanpa penambahan EM4. Pada pembuatan pupuk organik cair, EM4 dilarutkan dengan perbandingan 1: 9 (EM4 sebanyak $50 \mathrm{~mL}$ dan air sebanyak $450 \mathrm{~mL}$ ). Persentase dosis POC yang paling cocok untuk diberikan pada tanaman yaitu sebesar $10 \%$. Perhitungan persentase dosis EM4 dalam larutan pupuk cair (Andriani, 2020) adalah :

$$
\begin{aligned}
\% \text { dosis EM4 } & =\frac{\text { dosis EM } 4}{\text { dosis larutan pupuk cair }} \times 100 \% \\
& =\frac{50 \mathrm{~mL}}{500 \mathrm{~mL}} \times 100 \% \\
& =10 \%
\end{aligned}
$$

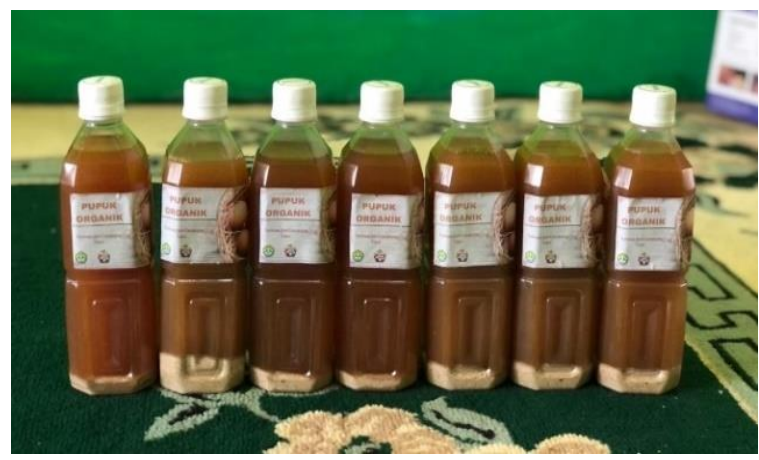

Gambar 3. Produk pupuk organik cair 
Larutan pupuk organik cair yang telah difermentasi selama 10 hari akan mengalami perubahan larutan menjadi warna cokelat lebih pekat, berbau aroma tapai dan terdapat gelembung di dasar botol. Hasil pembuatan pupuk organik cair dari $1 \mathrm{~kg}$ bubuk cangkang telur didapatkan 7 botol POC dengan volume $500 \mathrm{~mL}$ per botol (Gambar 3).

Hasil pengolahan limbah cangkang telur menjadi POC telah memberikan keuntungan sebesar Rp10.000,00 dalam setiap $1 \mathrm{~kg}$ bahan baku limbah cangkang telur. Selama praktik dihasilkan 7 botol POC berisi $500 \mathrm{~mL}$ per botol dengan modal Rp5.000,00 per botol. Pemanfaatan limbah cangkang telur sebagai POC dapat meningkatkan perekonomian kelompok ibu Pembinaan Kesejahteraan Keluarga (PKK) sebesar 50\%.

Setelah dilakukan pembuatan pupuk organik cair dan penyuluhan kepada warga RW 7 Kecamatan Rumbai Bukit diperoleh hasil produk POC yang telah tersedia di masyarakat. Kegiatan penyuluhan ini telah membuka wawasan masyarakat untuk memproduksi POC sebagai salah satu produk yang dapat dipasarkan secara mandiri.

\section{KESIMPULAN}

Pemanfaatan limbah cangkang telur oleh masyarakat di Kelurahan Rumbai Bukit telah menambah pengetahuan dan keterampilan dalam pembuatan pupuk organik cair. Antusias masyarakat meningkat sebesar 87,5\%. Aksi kegiatan penyuluhan ini menambah nilai limbah cangkang telur setiap $1 \mathrm{~kg}$ dapat menghasilkan $500 \mathrm{ml}$ POC yang dijual dan mendapat keuntungan sebesar Rp10.000,00. Pemanfaatan limbah cangkang telur sebagai POC dapat meningkatkan perekonomian kelompok ibu PKK sebesar 50\%. Aplikasi POC pada tanaman cabai dan pepaya yang ditanam di pekarangan rumah warga memiliki pertumbuhan daun yang lebih luas daripada yang tidak diberi POC.

\section{UCAPAN TERIMA KASIH}

Penulis mengucapkan terimakasih kepada Lembaga Penelitian dan Pengabdian Masyarakat Universitas Riau, Bapak Nanda Eddyan Harsono, S. STP selaku Lurah Rumbai Bukit, Bapak Masdi selaku Ketua RW 7, Ibu kelompok PKK yang menjadi mitra, dan masyarakat yang ikut serta dalam penyuluhan kegiatan KKN Universitas Riau tahun 2021 di Kelurahan Rumbai bukit, Kota Pekanbaru Provinsi Riau.

\section{DAFTAR PUSTAKA}

Andriani, V. (2020). Aplikasi pupuk organik cair Gracilaria gigas, cangkang telur dan kulit pisang terhadap pertumbuhan dan produksi sawi caisim (Brassica juncea L.). Teknosains, 14(2), 219-225. https://doi.org/10.24252/teknosains.v14i2 .15257

Brun, L. R., Lupo, M., Delorenzi, D. A., Di Loreto, V. E., \& Rigalli, A. (2013). Chicken eggshell as suitable calcium source at home. International Journal of Food Sciences and Nutrition, 64(6), 740743. https://doi.org/10.3109/09637486.2013.7 87399

Fan, Y. Van, Lee, C. T., Klemeš, J. J., Chua, L. S., Sarmidi, M. R., \& Leow, C. W. (2017). Evaluation of effective microorganisms on home scale organic waste composting. Journal of Environmental Management, 216 , 41-48. https://doi.org/10.1016/j.jenvman.2017.0 4.019

Gani, A., Widianti, S., \& Sulastri, S. (2021). Analisis kandungan unsur hara makro dan mikro pada pupuk kompos campuran kulit pisang dan cangkang telur ayam. Jurnal Kimia Riset, 6(1), 8-19. https://doi.org/10.20473/jkr.v6i1.22984

Hasibuan, S., Syafriadiman, S., Martina, A., Syawal, H., \& Rinaldi, R. (2019). Pendugaan laju sedimentasi pada kolam tanah budidaya ikan patin intensif di Desa Koto Mesjid Kecamatan XIII Koto Kampar. Riau Journal of Empowerment, 2(2), $71-80$. https://doi.org/10.31258/raje.2.2.71-80

Ji, R., Dong, G., Shi, W., \& Min, J. (2017). Effects of liquid organic fertilizers on plant growth and rhizosphere soil characteristics of chrysanthemum. Sustainability, 9(5), 1-16. https://doi.org/10.3390/su9050841

Kusumaningtyas, R. D., Erfan, M. S., \& Hartanto, D. (2015). Pembuatan pupuk organik cair (POC) dari limbah industri bioetanol (vinasse) melalui proses fermentasi berbantuan promoting microbes. Seminar Nasional Kimia dan Pendidikan Kimia, 1, 82-86.

Machrodania, Yuliani, \& Ratnasari, E. (2015). Pemanfaatan pupuk organik cair berbahan baku kulit pisang, kulit telur dan 
Gracillaria gigas terhadap pertumbuhan tanaman kedelai var Anjasmoro. Lentera Bio, 4(3), 168-173.

Noviansyah, B., \& Chalimah, S. (2015). Aplikasi pupuk organik dari campuran limbah cangkang telur dan vetsin dengan penambahan rendaman kulit bawang merah terhadap pertumbuhan tanaman cabai merah keriting (Capsicum annum L.) var. Longum. Bioeksperimen: Jurnal Penelitian Biologi, 1(1), 43-48.

Nur, T., Noor, A. R., \& Elma, M. (2016). Pembuatan pupuk organik cair dari sampah organik rumah tangga dengan bioaktivator $\quad \mathrm{EM}_{4} \quad$ (effective microorganisms). Konversi, 5(2), 44-51. https://doi.org/10.20527/k.v5i2.4766

Rahmadina, R., \& Tambunan, E. P. S. (2017). Pemanfaatan limbah cangkang telur, kulit bawang dan daun kering melalui proses sains dan teknologi sebagai alternatif penghasil produk yang ramah lingkungan. Klorofil: Jurnal Ilmu Biologi dan Terapan, 1(1), 48-55.

Saenab, S., Al Muhdar, M, H, I., Rohman, F., \& Arifin, A. N. (2018). Pemanfaatan limbah cair industri tahu sebagai pupuk organik cair (POC) guna mendukung program lorong garden (Longgar) Kota Makassar. Prosiding Seminar Nasional Megabiodiversitas Indonesia, 4(1), 3138.
Simanjuntak, D., Damanik, M. M. B., \& Sitorus, B. (2016). Pengaruh tepung cangkang telur dan pupuk kandang ayam terhadap $\mathrm{pH}$, ketersediaan hara $\mathrm{P}$ dan $\mathrm{Ca}$ tanah inseptisol dan serapan $\mathrm{P}$ dan $\mathrm{Ca}$ pada tanaman jagung (Zea mays L.). Jurnal Online Agroekoteknologi, 4(3), 21392145 .

Subandriyo, S., Anggoro, D. D., \& Hadiyanto, H. (2012). Optimasi pengomposan sampah organik rumah tangga menggunakan kombinasi aktivator EM4 dan mol terhadap rasio C/N. Jurnal Ilmu Lingkungan, 10(2), 70-75. https://doi.org/10.14710/jil.10.2.70-75

Suhastyo, A. A., \& Raditya, F. T. (2021). Pemanfaatan limbah cair industri tahu sebagai pupuk organik cair (POC) guna mendukung program lorong garden (Longgar) Kota Makassar. Jurnal Agrosains dan Teknologi, 6(1), 1-6.

Wijaya, V., \& Teo, S. (2019). Evaluation of eggshell as organic fertilizer on sweet basil. International Journal of Sustainable Agricultural Research, 6(2), 79-86. https://doi.org/10.18488/journal.70.2019. 62.79.86

Yunita, F., Damhuri, D., \& Sudrajat, H. W. (2016). Pengaruh pemberian pupuk organik cair (poc) limbah sayuran terhadap pertumbuhan dan produksi cabai merah (Capsicum annuum L.). Jurnal Ampibi, 1(3), 47-55. 